\title{
DISREGARD OF LEGAL ENTITY
}

\author{
Prof. Doctor Salomão António Muressama Viagem . \\ Doctor of Law in the specialty of Legal-Business Sciences from the Faculty of Law of the \\ University of Coimbra. \\ 00258824688560/00258847900045. E.mail: sviagem@svevigny.com \\ Eduardo Mondlane University . \\ Orcid 0000-0001-8420-3160
}

RECEBIBO 29/05/2019

APROVADO 30/06/2019

PUBLICADO 01/07/2019

Editor Responsável: Carla Caldas

Método de Avaliação: Double Blind Review

E-ISSN: 2316-8080

DOI:10.16928

ABSTRACT:

The theme of "disregard of legal personality [1] of commercial societies " is certainly not our creation; has already been discussed at the level of Portuguese doctrine and of other countries distant from us geographically and linguistically. Among the bibliographical material found in the scope of this study, we highlight the thesis entitled " The Guardianship of the Creditors of the Company by Quotas and the "Disregard of the legal personality" [2] and the comments made regarding the disregard, in article 5 of the Portuguese Code of Commercial Companies [3].

It should be noted that todo the legal institute's general grasp mister, distribute and protect interests. In turn, they are formed by legal relationships, which unite to regulate a certain and homogeneous portion of the legal reality.[4]

However, as SUZY KOURY teaches us, " every legal institute runs the risk of having its function diverted, that is, used contrary to its purposes. This deviation from function consists in the lack of correspondence between the aim pursued by the parties and the content that, according to the legal order, is proper to the form used. " [5]

In Portugal, it has already been argued that many of the cases ... may lead to disregard of legal personality through the teleological interpretation of legal and contractual provisions and through abuse of rights " supported by a substantialist solution of collective (non- absolutizing personality of the principle of separation) [6].

It is an institute that in our modest understanding represents a real threat to the theories of the legal personality of legal persons, especially of commercial companies. 
The legal personality of commercial companies have been created with the purpose of encouraging entrepreneurial initiative of a private nature, in designing the separation of the staff member s s heritage, $\mathrm{d}$ the commercial company, distinct entity that $\mathrm{s} b$ and $\mathrm{m}$ as the distinction of the legal personality of the person s s s partner's face the legal person (commercial company).

The piercing the corporate veil according to Professor de Abreu Coutinho, see the individual (partner (s)) a close link with society. [7]

The advancement and plausos to piercing the corporate veil is, in our view, among other things we will touch upon this study, a demonstration of setbacks or at least an appeal to review some legal institutes for many years underpinned the Law $[8]$; this being the reason that motivated us to develop the present theme. It is therefore questionable whether or not traditional law is still at the forefront.

The institute of" disregard " still shows itself to be far from reaching consensus on doctrine, visible in the diverging streams related to its implementation [9].

We will therefore present the general aspects of the issue, respecting what the pro Pósito has been said by the authors of the area and in a special way to present some problems that the application of the disregard of the Institute of legal personality of commercial companies raises, this is the goal.

We believe that the arrangements under corporate law associated with the Instituteabuse of right in civil law, it would be enough $\mathrm{m}$ to solve problems that did arouse piercing the corporate veil. We will, of course, deal only with the lack of consideration in the field of commercial companies, because it is where the debate has gained greater weight.

KEY WORDS : Disregard, Legal personality, Societies commercial purposes .

\section{RÉSUMÉ}

Le thème du "non-respect de la personnalité juridique [1] des sociétés commerciales" n'est certainement pas notre création; a déjà été discuté au niveau de la doctrine portugaise et d'autres pays éloignés de nous géographiquement et linguistiquement. Parmi les documents bibliographiques qui se trouvent dans le cadre de cette étude, nous soulignons la thèse intitulée "La tutelle des créanciers de la société par quotas et le" mépris de la personnalité juridique "[2] ainsi que les commentaires formulés concernant le mépris, dans l'article A leur tour, ils sont formés par des relations juridiques, qui s'unissent pour réguler une partie certaine et homogène de la réalité juridique [5]. Cependant, comme le dit SUZY KOURY, "tout institut juridique court le risque de remplir sa fonction. détourné, c'est-à-dire utilisé à des fins contraires. Cet écart de 
fonction résulte du manque de correspondance entre le but poursuivi par les parties et le contenu qui, selon 1'ordre juridique, est propre à la forme utilisée. "[5] Au Portugal, il a déjà été avancé que de nombreuses affaires (...) pouvaient conduire à un mépris de la personnalité juridique par le biais d'une interprétation téléologique des dispositions légales et contractuelles et par un abus de droit" étayé par une solution de type - personnalité absorbante du principe de séparation) [6]. C'est un institut qui, de notre point de vue modeste, représente une menace réelle pour les théories de la personnalité juridique des personnes morales, en particulier des sociétés commerciales.

La personnalité juridique des sociétés commerciales a été créée dans le but d'encourager les initiatives entrepreneuriales de nature privée, en prévoyant la séparation du patrimoine de l'agent, de la société commerciale, entité distincte de qn et $\mathrm{m}$ comme distinction de la personnalité juridique. de la personne sss face à la personne morale (société commerciale). Selon le professeur d'Abreu Coutinho, le percement du voile corporatif donne à la personne (partenaire (s)) un lien étroit avec la société. [7] L'avancée et la plausibilité de percer le voile corporatif sont, entre autres choses, à notre avis, une démonstration de revers ou au moins un recours en révision vis-à-vis de certains instituts de droit pendant de nombreuses années [8 ]]; c'est la raison qui nous a motivé à développer le thème actuel. On peut donc se demander si le droit traditionnel est toujours au premier plan.

L'institut du "mépris" se montre encore loin d'avoir atteint un consensus sur la doctrine, visible dans les courants divergents liés à sa mise en œuvre [9]. Nous allons donc présenter les aspects généraux de la question, en respectant les propos tenus par les auteurs du domaine et en présentant de manière particulière certains problèmes que l'application du mépris de l'Institut de la personnalité juridique des sociétés commerciales soulève, c'est le but. Nous pensons que les dispositions du droit des sociétés associées à l'Institut de violation du droit civil pourraient suffire à résoudre les problèmes qui ont soulevé le voile des entreprises. Nous ne traiterons, bien entendu, que du manque de considération dans le domaine des sociétés commerciales, car c'est là que le débat a gagné en poids.

MOTS CLÉS: Ignorer, personnalité juridique, sociétés

fins commerciales.

SUMARY: I - CONCEPTS

RELEVANT TO

THE

STUDY

OF THE DESCONSIDERAÇÃ OF LEGAL PERSONALITY. 1. Legal personality, 2. Moment of the acquisition ofcollective personality. II-DISREGARD OF LEGAL 
ENTITY . 1. Historical Aspects . 2 . Doctrinal constructions that seek to justify the " disregard of legal personality" .3 . Negative theories of the disregard of collective personality . 4. Point of situation. 5. General framework, cases of imputation and responsibility. 6. Cases of imputation and responsibility 7. Final notes . 8.Disregard in Portuguese Law. III CONCLUSIONS: Some problems of disregarding legal personality. IV - BIBLIOGRAPHY.

\section{CONCEPTS RELEVANT TO THE STUDY OF DISCONTINUATION OF} LEGAL PERSONALITY. [10]

\section{1. legal personality [11] - [12] .}

One of the pillars of modern law is the institute of the juridical person, created in the sense of overcoming the idea that the law only addresses the human being. Fictitious entities , juridical persons become subject of rights and obligations, passing from the universality of the members to an autonomous and independent unit. [13] Among the numerous theories on the juridical nature of the juridical person, the doctrine of Savigny, according to which, " person is every subject of juridical relations which, technically, does not correspond to a " natural person " but to be treated as a person through a theoretical fiction, in a situation that is justified, to allow a certain human scope " [14]

In particular, we are interested in the institute of "legal entity ", also it is said collective whose theoretical-legal foundation is legal personality. Its general function is to create a center of autonomous interests in relation to the people who gave it origin, in such a way that the latter can not be attributed the rights, duties and conduct of those. However, this communion of persons and goods must always be at the service of certain socially relevant purposes and, on the other hand, must also be lawful. [15]

As regards legal persons and, more specifically, with regard to commercial companies, ASCARELI teaches us that " the existence of a company can not serve to achieve an unlawful scope; the existence of a company can not serve to circumvent the norms and the obligations that concern its members; the existence of a coalition of companies can not serve to circumvent the rules and obligations which relate to one of the related companies. [16] One of the most effective mechanisms to react against this deviation of the function of legal persons is precisely the application of the theory of disregard of legal personality. [17] Legal persons are organizations constituted by a collective of persons or by a mass of goods, directed to the realization of common orcollective interests, to which the legal order assigns legal personality. [18] These are organizations composed essentially of persons or essentially goods, which are autonomous centers of legal-autonomousrelations even in relation to their members or to persons acting as their organs. [19] The category of legal persons includes the State, municipalities, districts, parishes, public institutes (such as 
the University), recreational or cultural associations, foundations, commercial companies, etc. [20] In the words of COUTINHO DE ABREU, we endorse : " Our purposes do not require a systematized and critical exposition of the various theories that have been tired of probing the juridical nature or the " essence " of the collective or juridical personality. Even because, on the one hand, this has already been done ( so less or more exquisitely) many times [...]; [21] on the other hand, such theories have proved to be inconsequential in determining and applying the law relating to legal persons (this right is determined by positive rules and legal practice, irrespective of " theories ", on the other hand, and without neglecting some notable ones contributions, the "theories " have not been revealed as " essential " of the collective personality [22]. And to a great extent uncommitted with the struggle of the dominant " theories " today in the doctrine the " technical legal " understanding of the collective person. As a product of the juridical technique, abstracting to a large extent from ethical legal and political-general considerations, not based on the metajuridic substrates their specific way of being, the collective personality appears as an expedient usable by many and different organizations ( institutional, foundational, associative, ), through which the legal system attributes to them the status of subjects of law, autonomous centers of attribution of legal effects" [23]- [24]

Continuing with the approach to aspects of collective personality, this time the light of civil lines proper. [25]

In the definition given of legal persons we refer to organizations constituted by a collective of persons and organizations constituted by a mass of goods. [26] There are in fact twofundamental species of legal persons : corporations and foundations. [27]

Corporations have a substrate made up of clusters of natural persons who pursue a common, selfish or altruistic interest. These people or associates organize the corporation, give it existence and it is up to them to discipline their life and destiny. They conduct it from within, having in their hands, through the modification of the statutes or other deliberations, the fate of the corporation. Corporations are sports associations, mutual societies, commercial companies, etc. [28].

The socio-economic function of the institute of collective personality is linked to the realization of common or collective interests of a lasting character. [29]

The interests of a plurality of people, possibly a regional, national or human community, are an undeniable fact: they are collective or common interests. Some of these interests are lasting, exceeding the lives of human beings, or, at any rate, justifying the creation of a stable organization. [30]

For the pursuit of these common or collective and lasting interests it may be convenient or even essential to structure a coordination of goods and personal activities of the interested parties in space and time. The legal treatment of this organization of goods and 
persons as an autonomous center of legal relations will make it easier to achieve the desired interests or will be the only way to achieve them. All the juridical relationships constituted in the activity directed to the target scope are headed in the organization as center of a legal sphere. It is the subject of these legal relationships, applying them the rules of private law in the same terms as they apply to natural persons. [31]

Instead, great difficulty or even impossibility of achieving true and lasting collective interests in deparariam, if there were such a mechanism, this technical and legal instrument, which is the legal personality or legal personality of legal persons. He would then have to resort to legal collective personality of interested individuals, which would be difficult, complicated, precarious or insufficient. [32]

\section{Time to acquire the legal personality of commercial companies .}

Recognition is the element of law, reducing the dispersion and plurality of the substrate to

unity, to the quality of subject law. [33] Among us, the normative recognition conditioned in the commercial and civil societies in commercial form and of the associations and the recognition by concession is required for the foundations. [34] The regime established in the CCom.de 1888 did not make it possible to say with certainty that commercial companies ( all commercial companies) had legal personality. It is true that the dominant doctrine considered [35] based on ( but not only) the provisions of Article 108 of the CCom . But the truth is that there were still some discordant voices. [36] At present, the problem is solved by Article 5 of the CSC, according to which " companies have legal personality and exist as such from the date of definitive registration of the contract by which they are constituted, without prejudice to the provisions regarding the formation of merger, spin-off or transformation of others. With the definitive registration of the company agreement, commercial companies ( all commercial companies) acquire legal personality. And they enjoy that legal personality both in relation to third parties, and in relation to the partners themselves. [37] Thus, it is the company (with commercial object) that acquires the status of merchant as a consequence of the exercise of the social activity and not the partners.Therefore, it is the company that is subject to the obligations imposed on the merchants and not its partners. In addition, the company may have rights against its partners. [38] As a consequence of the attribution of legal personality to commercial companies, we have, first of all, that these companies are holders of rights and obligations. The rights and obligations of the company are therefore not rights and obligations of the partners. The shareholders have neither rights over the isolated assets of the company nor the assets of the company as a whole. [39] 


\section{DISCLOSURE OF LEGAL PERSONALITY [40] - [41] •}

\section{Historical aspects}

The subject of disregarding first appeared in US law based on the theory of " desregard " of legal entity . " [42] " In reality, the first decision in which the North American courts will have applied the principle of de sregard of the legal entity doctrine or what it came to be called, piercing the corporate veil, dates back to 1809 , in the case Bank of the United States " [43]

However, although jurisprudence provided a wide field of investigation, the dogmatic framing of the problem was not done, as is, incidentally, the stamp of Anglo-American systems.

However, the question raised the awareness of continental European lawyers and even South American lawyers, but particularly the Germans.

In Germany the problem arose from the work of the courts. Until 1920, only the strict separation between the legal person and its members had been taken into account .

Only in its judgment of 22.06.1920 the 3rd Senate of the Reichsgericht ( RG) abandoned that initial position.

In this case, referring to a -unipessoal $\mathrm{GmbH}$ (where of course the problem is most evident), the RG based its decision on the formula, later widely used, that the judge should, before the legal construction, pay attention "the reality of life and the strength of things. " Although the judgment had not gone uncritically, it was the turning point that would generate all future discussion. Other judgments followed him that support the "nature of things" in the "prominence of the reality on the way" in the "bypass the law", the "dominant popular consciousness," or the "economic needs", justifying decisions of the same type.

All this took place under the backdrop of abandonment to legal positivism and the progressive shift to the jurisprudence of Heck's interests .

In the pre-Second World War doctrine, two main currents of opinion were confronted.

Through the first, it was tried to maintain the separation between the companies and their partners, trying to find a solution to the problems detected in the general rules of civil law.

By virtue of the second, the sole proprietorship and its partner were identified, based on the parallelism of interests existing between both subjects.

In the first decade of the post- war period, jurisprudence was mainly concerned with the problem of identifying Reich societies with Reich-the so- called problem of war societies. It was in question whether the debtors of Reich companies could offset their debts with their claims against the Reich.

Some jurisprudence has denied the invocation of separation and the consequent autonomy of property by virtue of a breach of good faith, thus recognizing the reciprocity of claims and 
debts. In its judgment of 03.07-53 the Bundesgerichtshof (BGH) clarified in more detail the assumptions which, once assembled, made it possible to admit that there is " an abuse of the formal legal position of the Reich society as an autonomous legal person " and therefore also an breach in good faith .

In that judgment, the BGH takes account of the fact that the company does not have any social life of its own " that the share capital, which was made available to it by the Reich, remained " affectedfor certain purposes " and that the company was " a mere instrument " of the Reich.

Although the judgment was self-limited to cases where there was a close link between the reciprocal credit and the field of action of the war corporation and even where the decision is dogmatically based on paragraph 242 of the Burgerliches Gesetzbuch (BGB), there are similarities with the argumentation of the " theory of the patrimony of special affectation " that came back to come alive next to the doctrine. Indeed, as early as 1953 SCHILING had attempted to consider the sole shareholder company with no legal personality considering it as a mere asset of the special allocation .

However, this theory, which was strongly opposed by many authors, was not enforced.

Also related to the problem of single-person societies was also debated, in this post-war period, if responsibility - according to the principle " KeineHerrschaft ohne Haftung " - which would be a mainstay of the market economy, has fallen into a commonplace that still influences the discussion today.

In summary, it can be said that the period med i u between 1920 and 1955 were mainly the cases of Single shareholdership that focused the attention of the doctrine and jurisprudence, but the discussion was developing in different directions and from bases different.

There was, therefore, a systematic treatment of matter, a point of crystallization from which discussion could be made.

As one stated, " in those times the discussion had no common platform, no one could be found . " [44] - [45]

\section{Buildings doutrin aria s seek to support the disregard of legal personality " [46]}

In order to control abuse, in flagrant reaction to the absolute interpretation of the principle of autonomy, the doctrine of " disregard of legal personality ", known as di sregard doctrine , by which it is possible, in certain situations, to disregard the legal personification of the fictitious entity to avoid a result incompatible with the function that the Law granted him. It is, therefore, a true instrument of perfecting the institute of the juridical person, since, on the one hand, it allows its primordial function to be achieved, on the other, it prevents the use contrary to the Law. [47]

The absolute character of the personification is thus denied, to the point of disregarding a most 
valuable institute by which the juridical form borrowed from the legal order is dispensed with, removing the veil from the personification of the collective entity, certain factual circumstances in which there is abuse of rights or fraud [48].

Disregard, however, does not imply extinction of the legal entity, which is preserved in the face of other non-fraudulent acts that it has practiced. There is a temporary suspension of the personification for a specific moment or act, characteristic of this institute, in the face of nonobservance of the function for which fiction was created. [49]

In order to justify the application of the institute of the " disregard " of the collective personality, some of the theories for and against were presented, which we will highlight next .

In the analysis of the theories historically emerged to explain and justify the use of a solution, deserve the first reference calls "subjective theories of abuse." Its main representative is R OLF SERICK.According to SERICK, the autonomy of the legal person may no longer be taken into account when this juridical form is used inter- nationally, " by the natural persons who hide behind [50] "Of the legalperson, for purposes other than those that were the origin of its personification by the legislator. This match thesis-point for theories of abuse-it is clear the role of legal reprehensibility, which is explained: SERICK came to question, in a systematic way the absolutism of the legal status of legal person, which implied to put that labor great caution, as well as the restriction of recourse to " disregard of thecollective personality " in cases where such a solution might seem indisputable, as is the case where there is a conscious abuse of the legal person. From a methodological point of view SERICK guides its exposition around the identification of groups of cases, three large groups of situations in which the use of the legal person is abusive, characterized by the intentionality in obtaining the abusive result: fraud to the law (when reaches a result prohibited by law by a route other than that which is normatively considered, whenever the ratio of the rule is withdrawn that it is intended to prevent the production of that result, and not only its realization through the use of the medium to which the precept considered), fraud and contract damage (which consists of the use of the legal person to pursue a result contrary to the express-purpose or clearly identifiablecontract), and fraudulent damage caused to third parties through the legal person. It should be noted that the fact that SERICK depends on a solution of the international character of the abuse of the institute of the legal person has made its constitution a very restrictive and even a reductive

one. [51]

ROLF SERICK, [....] Formulated the following four propositions: a) when a legal provision, a contractual obligation or a prejudice to a third party or an abuse of the legal entity exists through the legal person, only in these three cases it is possible to disregard the legal entity, since the principle of good faith has been violated; b) to disregard the legal entity, it is not enough to claim that this remedy is necessary for the fulfillment of the law or a contract; (c) 
where legal provisions establish situations which take into account specific human values, or certain qualities thereof, then those values also apply to legal persons; d) If the form of the legal entity is used to conceal that there is in fact identity between the persons involved in a given act, and for the legal norm to be fulfilled requires that the identity of the interested parties is not purely nominal but affective, then it will be possible to disregard the legal personality. [52]

It was inevitable that the solution proposed by SERICK found himself confronted co ma same question that debate concerning a design subjectivist view of abuse of rights: the very conception of abuse of rights can only be based on objective criteria, since the requirement of conscience of abuse would benefit" those who know no scruples . "That is why any legal construct based on the notion of abuse turns out to be objective, centered on the objective excess in the exercise of the right ( although subjective considerations are always relevant in cases of violation of the limits imposed by good faith and good manners; already the limit of the "social or economic end" of the right represents the consecration of a purely objective criterion ). Also within the scope of the dogmatic grounding of the "disregard of the juridical personality " of the legal person this path was traveled, reason why they quickly gained space, in this field, institutional theories or the objective abuse. As a result, the new analyzes have begun to consider relevant an objectively unlawful use of the legal person institute, as the German courts have stated early on and has been defended by the doctrine and jurisprudence of the other European countries. Moreover, the very operation of the mechanism " disregarding the legal personality" would be seriously compromised by the difficulties that can prove the subjective element . [53]

In the light of the institutional theory of " disregarding legal personality ", a solution must be found when the separation between association and member goes against the legal order, and abuse is understood as the use of the legal person against its institutional purpose, through fundamental principles of the legal and economic system. Rightly KARSTEN SCHMIDT note that this movement has the advantage of retracting the mechanism "piercing the corporate veil" punitive charge, but simultaneously makes it increasingly difficult to definition and

justification. [54]

As an alternative to the constructions that, for a solution, start from the abuse of the law ( subjective or objective), the so-called theories of the application of the norm appeared. In this context, the construction of MULLER-FREIENFELS ( in response to the positions of SERICK), which sought to solve problems in the light of the meaning and purpose of the rule whose application is at issue, whether this rule will apply to the legal person. For this theory, the legal person is not "unity" so that the question can not be a generalized problem of the legal status of the legal person: it is a problem of implementation of the standard. The legal person is a symbolic image, an expression designed to represent a complex of juridical relationships and norms. The center of attention diverges from the legal person itself to 
the standard to be applied, an operation to which " its purpose, its function and the interests that it oversees should be sought. "However, it can still be considered a theory of " disregard of legal personality", in that it still deals with the principle of separation between the legal person and its members and the limits of the right holder, and not only the application of rules to such holder of rights. From the methodological point of view, a restriction of the norm that gives expression to the separation between the legal person and its members, and the consequent supply of this legal space through the application of another norm, is at issue. A theory of the application of the norm thus defined is in fact very close to the institutional theory of the disregard of legal personality, since it relativizes the institutional scope of the principle of separation: this principle of separation - or one of the rules reflecting this principle (as is the case with the rules establishing limited liability of members of limited companies and shareholders of public limited companies) - will be limited. But the theory of the application of the rule differs from the institutional theory or objectivetheory of abuse by the fact that from a different dogmatic-legal understanding of the legal person (Which is no longer seen as a legal whole, but rather as a mere mental picture, mental synthesis of facts, individual relationships and standards), towards its relativity: the understanding of the essence of the legal personality of the legal person does not lead to technically comprehensive legal subjectivity [55].

\section{Negative theories on "Disregard of legal personality" of the legal person .}

Finally, a special reference is made here to the so-called negativist theories, that is, that they reject the possibility of existence of the " Disregard of legal personality " . A pioneer in this attitude solutions have been the position of ERICK Schanze in Einmanngesellschaft work und Durchgriffshaftung, 1975. SCHANZER seeks to solve those same problems that the doctrines solve (through recourse to "legal personality "of the legal person ), but using a solution completely disconnected from ideas, since the operation of imputation to making use for this purpose is no longer defined as a penetration in the legal personality or a return to the idea of relativity of legal capacity of the legal person. In SCHANZER, the problem of imputation, interpretation and application of the norm is the coexistence of the association and its members. Therefore, a problem is a real problem of interpretation of the rules governing the organization of legal persons and of the provisions governing the external relations of society with third parties; as the coexistence between the association and its members" is the starting point " for problems of imputation, interpretation and application of rules, the solution can not consist in disregarding the legal personality of that association, nor in its relativization. [56]

The movement of rejection of the doctrines will gain expression, especially, from the eighties.Increasing criticism of the problems solution proposals that pass by disregard " disregard " or the " relativity " of the legal 
personality of the person collective and begin to proliferate alternative construction proposals. [57]

\section{Point of situation. $[58]$}

egardless of the position you take on the question of " piercing the corporate veil " - whether it passes the defense of the need to recognize the autonomy dogmatic figure, either by their denial, or by some compromise between ambos-, it should be recognized to these theories of the merit of trying to establish some rigor in the analysis of the problem. This rigor is manifested in the fact that all these authors leave of reality that is the legal personality of the person collective, reality that, once recognized by the legal system, can not be called into question at every step on behalf of the pursuit of justice of the case ( in the background, " equity" ); such an orientation would represent an incoherence of the legal system itself and would eventually lead to a real crisis of the institute of collective personality . [59]

The other lesson that can be drawn from the theses exposed as negative theories is that a solution should not be resorted to when the institute is disregarded when a fair result is possible through recourse to solutions resulting from the law (from the application of rules interpreted) or contract. Above all, in cases where the liability of members is intended to safeguard the interests of the social creditors, it should be avoided, as will be seen, any solution that implies the sacrifice of the legal personality of the commercial company, when unnecessary (note that this sacrifice jeopardizes the security and stability of the institute person legal, not only at a generic level, but still in the concrete case. In effect, once it is " disregarded " judicially it will be prevented from continuing to participate in legal traffic; however, this disregard will produce more lasting effects than it may seem, since " the risk of abuse in relation to the legal person [..... ] subsists after the lifting of the veil " ). For more, as will be shown in most cases considered of responsibility, the satisfaction of the company 's creditors can also be achieved through the proper functioning of the legal and corporate rules that predict, in certain circumstances and with certain assumptions, direct liability of the members of limited liability to the social creditors, or through the strict application of the rules that establish the " internal " responsibility of the member before the society or even through the use of the figure of the administrator in fact. [60]

The truth is that in the different legal systems where the question of "disregarding the legal personality" of commercial companies found fertile ground for implementing the responsibility of members for social services was a means by which doctrine and jurisprudence sought to solve specific problems of protection of the social creditors - problems for which the interpreters demonstrate not find adequate solution by means of the immediate recourse to the legal dispositions in force in the social-legal domain. And perhaps the great difficulty always felt in the attempt of dogmatic justification of the " disregard of legal personality " lies, after all, simply because we are not dealing with an ' institute ', but rather with 
the attempt to obtain a particular result which, in particular, seems the most just. Basically, the elaboration of " case groups " results from the fact that there are groups of situations in which there are problems that the immediate legal solution of which the interpreter does not conform; in common, these cases seem only to be capable of eliciting the need for a solution. The evident functionalization of the alleged " institute " to the intended result has prevented those who defend its application from identifying a legal core common to all life situations to which it might be able to apply, which makes it more acceptable, at least at this stage, the reference to a " method ", " mechanism ", or " solution ". [61] Simply, it is first of all ascertain whether the desired accountability effect of limited partners goes, indeed, the "piercing the corporate veil " of the company concerned, or if we can be, in particular, before a phenomenon of nature different. Then, in order to better understand the meaning and scope of this mechanism, it is necessary to analyze the so-called " groups of cases " to which it is usually applied: that this application has known evolutionary movements, both in terms of doctrine and jurisprudence. In the light of a current state of affairs, an attempt will be made to answer the question of

" Auto nomy" of this means of accountability of the member of limited liability by the social obligations. [62]

\section{General framework, cases of imputation and responsibility .}

The " piercing the corporate veil of the person collective", reveals relativism or absolutism no legal personality . [63]

Societies-legal entities are, as already mentioned, autonomous subjects of rights; are " separated " from their members ( partners) - other autonomous subjects of law. However, this separation must not obscure us. Society does not live by themselves and for themselves before there is by and for the (s) partner (s); these are her instrument (there for close connection between one and the other). On the other hand, the assets of the company is not in the service of interests of the corporation "itself" but the $(\mathrm{s})$ partner $(\mathrm{s})$. Now, it is this substantialist consideration of the collective personality which opens up ways of " disregarding" it in one or another case; is to take account of the personal and / or patrimonial substratum of society which sometimes induces the "lifting of the veil "of personality, to derogate from the so-called " principle of separation " ( Trennungspritenzip ). [64]

We can then define the disregard of the collective personality of companies as the derogation or non-observance of the subjective legal and / or patrimonial autonomy of the companies in the face of the respective partners. [65] Another definition according to Pedro Cordeiro: We disregard disrespect for the principle of separation between the legal person and 
its members or, in other words, disregard means to derogate from the principle of separation between the legal person and those behind it they act . [66]

Such a disregard will legitimize itself through recourse to legal practitioners, such as (and as appropriate) the teleological interpretation of legal and negotiating provisions and abuse of rights - by a substantialist conception of collective personality ( not absolutizing the " principle of separation "). It is thus a methodical building consists of two main pillars ( abuse of law and teleological interpretation), more or less traditional, and a base ( less traditional and rooted) that supports and power to design substantialist, not formalistic or absolutist of collective personality ( there is no impassable boundary between society and partner. [67]

To implement systematically the method of disregard of personality legal, must be distinguished from the i s " cases of groups " : the group allocation of cases - certain knowledge, qualities or behaviors of members are referred to or allocated to society and vice versa- and the group of liability cases - the rule of limited liability ( or non-liability for social debts) that benefits certain partners ( in particular private limited companies) is broken . [68]

If in addition to the perspective substantialist personality collective, the operator teleological interpretation dominates the group of case allocation, as in the group of cases of responsibility is dominant abuse of the right: the partners lose the benefit of " limited liability ", responding to the creditors social, when they use the "institute " society-legal person ( in principle with perfect patrimonial autonomy) not ( or not so much) to satisfy interests of which it is instrument, but to disrespect interests of the creditors of the society; or, as the wording of Article 334 of the CCiv., When they exceed the limits imposed by the social or economic purpose of the right to set up and operate ( or not) society. [69]

It is not possible to draw up a catalog of phenomena, situations or problems in which the practice of lifting the legal personality can be an adequate instrument or even necessary to obtain solutions that are adjusted to material justice, based on the exact valuation of interests that are at stake in each case; which means strip the corporate formal dress to prove who are the ones who are behind the garment, which is the same as ignoring their pleas jur IDICO s as if there were a legal entity. This, of course, in those cases in which the interpreter of the Law elects the appraisal that the legal entity was constituted for the purpose of fraud or of the law or the interests of third parties, or when-not as an objective, but as a result the use of the formal coverage in which the legal entity consists leads to them fraudulent effects . [70]

Nonetheless, the doctrine has rehearsed various enumerations of, so to speak, cases in which the formulation of the lifting of the veil finds more justified and reasonable application. [71]

De LA CÁMARA, for example, cites the situations concrete applications of the lifting of the veil: firstly, cases in which the formation of a society to deceive the performance of a contract, to circumvent the rights of third parties or to evade the law is 
simulated; secondly, where it is having been raised the problem, using a solution of the " ratio " of legal personality, ie the perpetrator invokes the legal personality of the company to defend themselves . [72]

6. Cases of imputation and responsibility. [73]- [74]-[75]-[76]

COUTINHO DE ABREU, along the path of theoretical elaboration of the assumptions that lead to the disregard of legal personality, presents and, as a pioneer in this construction in Portugal, two groups of cases, imputation and responsibility, with a range of examples for each group of cases . LAMBS MENEZES [77], in turn, also aligned in the direction of application of slight, choosing the terminology "lifting" couple Tindo cases listed by Herbert Wiedemann features as cases for the occurrence of the figure here occupies in a set of situations that in our view only deviate from those indicated by COUTINHO DE ABREU in the linguistic formulation, being in addition the exception of the case of the attack on third parties), which is reducible to that construction. The following cases [78]:

- the confusion of legal spheres;

- undercapitalization ;

- the attack on third parties;

- the abuse of the institute.

\section{Final notes.}

Also according to COUTINHO DE ABREU: " As is clear from the name itself, the problem of disregard is usually referred to legal personality. However, we have seen that societies without legal personality also have legal subjectivities. Well, all or almost all of the personality disregarding examples pointed out can also be referred to non-personalized societies. There is also room, therefore, for the " disregard of legal subjectivity .

In spite of the criticisms that have been addressed (" dogmatic "deficits, of sharpness, certainty and security, etc.), the disregard of collective personality (and legal subjectivity) is very capable of counteracting some dysfunctions of the societies perpetrated by partners. " [79]

\section{Disregard for Portuguese Law [80]- [81].}

In Portugal, the matter of " disregarding legal personality triggered in the 60 's, with the cases, [.... . ] "Handy-Angle Portuguesa-Cantoneiros Metálicas, Lda. " Jorge Valentim de Almeida and his wife and society " Joaquim In 1964, the members [...] were divided into two groups: Jorge Valentim de Almeida and English society, the other Manuel Homem de Melo, and Nelson Albuqerque reis. Therefore, in order to put an end to such a situation, they will come to an agreement ( in July 1964) in the following ways: Jorge Valentim de Almeida and the English 
company would cede their quotas to the other two partners for the price of $300.00 \$ 00$ each (thus abandoning the company); the agreement between English and Portuguese society for the manufacture of the products by the licensees [..... ] and, in addition to other special clauses, the four primitive partners were committed " not to manufacture a like product in the Portuguese territory "for as long as the agreement between the two Handy- Angles lasted .

Leaving the Jorge Valentim de Almeida company dedicated completely to society " Joaquim Valentim de Almeida \& Filhos, Lda." , Founded by his father, and from March 1965, is that you have $95 \%$ of the share capital, while the remaining $5 \%$ belong to his wife - D.Lidia Valente de Almeida - with whom he is married in a regime of general communion of goods. The company began to market products identical to those of HandyAngle and hence the action brought by it on the grounds of breach of the undertaking given in July 1964. Mr Jorge defended himself, arguing that it was the separate legal company, which did not enter into any agreement - and not he, who is manufacturing and marketing such products [82].

On this case, two opinions were prepared by renowned jurisconsults of the time, namely, Professor ANTUNES VARELA and FERRER CORREIA, who, although based on different assumptions, came to conclusions consistent with " disregard " [83]. The said case was solved extrajudicially. [84]A second prominent case, it was invoked the " disregard ", by their authors ( Alvaro and Ilídio and their wives) on the application, was the ARSOPI-Industrias Metalurgicas Vinh S. Pine, Ltd. Submitted case the appreciation of professor G Alvao T tHEY, which for this purpose studied the works of IF RICK and VERRUCOLI concluded by failure to apply the " disregard "

because it understood that the conditions for its application were not met. [85]- [86] The Portuguese legal order did not adopt a specific legal provision expressly establishing the admissibility of the figure of " disregard "[87]. But there are provisions in the CSC, which are reflected solutions desconsiderantes as in the case of articles $84^{\circ}, 501^{\circ}$ and $502^{\circ}[88], 180$ ${ }^{\circ} \mathrm{n} .4,254$ th $\mathrm{n} .3$ and $477^{\circ}$ also the CSC [89].

The article $78^{\circ} \mathrm{CSC}$, is not a part as solutions desconsiderantes in relation to managing partners. [90]- 91] In terms of comparative law, Mozambique adopted clearly and expressly the figure of "disregard of legal personality" as seen in Article 87 paragraph d its recent Commercial Code which provides entitled (Disregard of legal personality ).

The legal personality of the company will be disregarded and the partners will be held liable when they act guilty or willfully in the following cases: a) the company is used as an instrument of fraud and abuse of economic power; b) violation of the essential consumer rights and the environment; c) in any case where the legal personality is used in order to harm the interests of the partner, the employee of the company, third parties of the State or the community where the 
company acts; d) in the event of insolvency of the company of the same group of companies when defined in special legislation . [92]

The Mozambican legal system, seems to have put on auction the legal personality of companies by allowing a wide range of assumptions that allow the use of this action. Is this the best solution?

With regard to the case law in Portugal, most of the judgments in which the issue of disregard was raised, opted for solutions extracted from Company Law in conjunction with Civil Law. [93]

Apparently, the " piercing the corporate veil " as such, has not won applause sufficient for his statement in Portuga 1 .

\section{CONCLUSION : SOME PROBLEMS OF DISCONTINUING LEGAL PERSONALITY}

1. The " disregard of legal personality" does not seem to be a legal institute as such, since, in addition to having no theoretical-doctrinal consistency, it has not been commonly applied in jurisprudence. A legal institute must have a robust theoretical-doctrinaire basis, that is, of little shaking, and should be useful in the field of application of the Right without great reservations

[94].

2. It represents a great risk to entrepreneurship through a commercial company, to the extent that, if devaluing, or to be considered as relating to "legal personality ", increases ha fear the entries in corporate life, since it is always exposed the personal assets of the ( $\mathrm{s}$ ) partner ( $\mathrm{s}$ ) towards the company creditors. When establishing the legal personality of companies,

If as a main objective to encourage activity enterprise (entrepreneurial), avoiding ISS the , ri sco face of the personal assets are bonds business .

3. It can be questioned who actually reaches the disregard, only the ( $\mathrm{s}$ ) partner (s) culprit ( s) ? administrators, controlling partners or any partner?

4. In societies where

the

dynamic of entry and exit of members is greater, where one can verify the phenomenon of ( multiplicity and variety of partners), how to reach the patrimony of those who just entered or leave?

5 . In procedural terms, the question arises as to what kind of procedure is being asked to disregard it? Action declarative or executive? Or would it be an instance incident? Or was it a special process?

6 . It is not understood why to disregard the legal personality of the company, whether there are norms in the area of Civil Law and Civil Law that solve problems of fraudulent or 
abusive conduct of the Law, of any person, regardless of whether or not he is a member, as well as norms which hold society accountable to creditors.

7. The Portuguese jurisprudence leans more to use the figure of the "abuse of $\mathrm{d}$ ight ", where rise aspects of the doctrine of disregard.

The problem is not the legal personality of the society but the " heritage that is in their ownership", the behavior human to " hide behind it or use it for different purposes than those for which the law allows its constitution ", " use of the veil of legal personality ". Therefore society is created and used, it never uses itself, it does not act for itself and for itself .

9. In a society complex and consists of several partners that are ( corporate business), it would be necessary to raise " several veils" to reach the people concerned and this no doubt, would long s march s processua is the level of the courts with the necessary related costs to these various inconsistencies.

10. It seems to us that the problem of disregard is related to that of "passive legitimacy, " Institute of Law Proce s Civil sual, which should be further extended and the light of the right to abuse or " institutional " [95] of the legal person, in order to weaken its use as a dilatory exception .

11. Such c omo the predecessors of this study, the disregard, "ignores " the theory of legal personality, or at least, undermines the consistency and effectiveness.

12. According to ENGRÁCIA ANTUNES, The groups of companies-structure and legal organization of the multi-company company, 2nd ed. $\quad, r$ evista and updated, Almedina Coimbra, 2002, p. 559, groups of societies constitute one of the "grounds of choice " of disregard. This means that 'the attribution to the parent company of liability for the consequences of acts or omissions which, although formally committed by the daughter companies, may be attributed to the material control of that company. " [96] companies

13. Disregard of legal personality, applied to traditional

[97] (eg. By quotas ), in which the partners are only individuals, makes the overall insecurity heritage no corporate or personal the ( $\mathrm{s}$ ) partner ( $\mathrm{s}$ ), including their " rel e quias ".

14. The introduction of " disregard ", first by jurisprudence followed by doctrine and later accepted by some legislations, reveals the old Enlightenment idea that man is the center of all things,

he is indeed the subject of rights and obligations. It is also, a clear recognition to the fictional theory of legal personality ( the legal person is a simple fiction).

15. The doctrine of " disregard of legal personality " has as one of the great merits the reconsideration of the legal personality institute with a view to its reaffirmation or not ( absolutization or not). 
16. Ultimately aligned with the idea that what should be done is not " disregard the legal personality of commercial society " as such, but depart from the heritage of separation, based on the case law formulation [.....] derogate principle of separation between the corporate entity [98] and persons acting on behalf of and acting on behalf of [and] acting . [99]

\section{BIBIOGRAPHY}

ABREU de, Jorge Coutinho, Course on commercial law, vol.II, das sociedades, Coimbra, 4th ed, Almedina, 2011

Of the entrepreneurship ( The companies in the right), Almedina, Coimbra, 1996. Diá logo $s$ with the case, II-Liability of directors towards the company creditors and piercing the corporate veil, Company Law in Review (DSR), Almedina, Coimbra, 2010, p. 49-64

Abuse From right- Test a criterion in civil law and in corporate decisions, Almedina, Coimbra, 1983 ( reim p .1999,2006)

Governance of commercial companies, Almedina, Coimbra, 2006.

Introduction, acts of commerce, merchants, companies, distinctive signs, 7 th ed., Almedina, Coimbra, 2009, " Dialogues with jurisprudence

Liability of the managers towards social creditors and disregard of legal personality " DSR 3,2010, P.49-64;

Responsibility of corporate managers, 2nd ed., IDET, Almedina, Coimbra, 2010.

AYALA

Garcia,

Juan Mateo : La doctrina del " survey del velo ". Its applicability in criminal

proceedings. Aspects nouns y criminal proceedings, Revista Española de Seguros, April junio 1996 num.86, pp.51-65

ANTUNES, José Engracia -Right of societies, ed. Do A., 2010 .

The groups of companies-structure and legal organization of the multi-company company, 2nd ed., Revised and updated, Almedina, Coimbra, 2002 .

ANDRADE, Manuel, General Theory of Legal Relationship, I, reimp ., Almedina, Coimbra, 1983.

ANGEL YAGAYZ, Ricardo de. The doctrine of the lifting of the veil of the juridical juridical person in the jurisprudence, 4th ed., Pusta a day and extended, Madrid: Editorial Civitas, 1997. 
ANTUNES, A.Filipa Morais- " The abuse of legal personalitylegal in company law commercial" in AAVV., New trends of liability, Almedina, Coimbra, 2007.

ASCENSÃO, José Oliveira- Commercial Law, vol.IV - Sociedade comerciales, Lisboa, 1993. 2000.

Commercial law, vol. IV-Commercial Companies. Part General, Lisbon

ALBERTON, Genaceia da Siva, "The Disregard of the Legal Person in the Consumer Code " , in " Revista de Direito del Consumidor ", vol VII,

a publication of the Brazilian Institute of Consumer Law, July-September 1993, Editora Revista dos Tribunais.

ALMEIDA, Pereira de, Commercial societies and securities, 5th ed., Coimbra Editora, Coimbra, 2008 .

AMARO, Luciano," Disregard of Legal Personality in the Code of Consumer Protection ", in "Revista de Direito do Consumidor ", vol.V, a publication of the Brazilian Institute of Consumer Law , January-March 1993, Revista Revista of the Courts.

BOLDÓ Roda, Carmen : The veiling of the veil and the legal personality of mercantile companies . Madrid, 1993 "levantamiento del velo y persona legal en el D erecho private Spanish", Aranzadi, Pamplona, 1996.

CASTRO, F r ederico and Bravo, The legal entity, 2nd ed., Civitas, Madrid, 1984.

CAMPS Ruiz, Luis Miguel: La corporate responsibility en los groups of companies within del number of Cuadernos de Derecho Judicial dedicated to aspects laborales of them business groups, Madrid, 1994, pp.7-40 .

CAMPILA Rongero, Francisco : The legal person: functions and dysfunctions, Madrid 1984.

C ODE $D$ the Sociedades Commercial C OMMENTARY, Note to Article 5, AAVV ( coord.de Coutinho de Abreu), Almedina, Coimbra, 2010. 
CORREIA, Brito, Direit o Comercial , $2^{\circ}$ vol., Association Ac adémica of the Faculty of Law of Lisbon, Lisbon, 1989, p.244

De Castro, Federico La sociedad anonymous y la deformation del concepto legal persona, Yearbook of Derecho Civil, 1949, pp.1397 y sigs . pp.943 y sigs . offensive against el concepto legal persona, Yearbook of Derecho Civil, 1961, Formacion y deformation del concepto legal persona (Preliminary notes for el studio it legal persona ), Centenario de la Ley del Notaries ( various legal studies), seccion third, vol. 1, Madrid, 1964, pp.85 y sigs

The legal person, Madrid, 1981.

DOBSON, Juan M. El abuse her personality jurídica-en el derecho private. Buenos Aires, Depalma, 1991.

COELHO, Fábio Ulhoa, " Disregard for Legal Personality" , 1977, São Paulo, Editora Revista dos Tribunais.

COELHO, Pinto, Lessons in Commercial Law. Commercial bonds in particular ( commercial companies), author's edition, Lisbon, 1966.

CORDEIRO, Pedro- The disregard of the legal personality of commercial companies, AAFDL, Lisboa, 1989;

CORDEIRO, António Menezes. The survey of collective personality in civil and commercial law . Coimbra: Almedina, 2000.

Company Law Manual, I- Companies in general, Almedina, Coimbra, 2004. Commercial Companies Code annotated (coor.de A. Menezes Cordeiro), Almedina, Coimbra, 2009 .

CORREIA, Ferrer, " The company limited by shares under the Companies Code ", in matters of commercial law and private international law, Almedina, Coimbra, 1989. Lessons in commercial law, II, João Abrantes, Coimbra, 1968.

CORREIA, Brito , Commercial law . $2^{\circ}$ vol ., Commercial Societies, AAFDL, Lisbon, 1989.

CORREIA, M.Pupo - Trade-Right Law Company, 11th ed. ( C / colab De. AJTomás / O.Castelo Paulo), Ediforum, Lisbon, 2009: 12th ed, 2011. 
COING, Helmut- in J.Von Staudingers Kommentar zum Burgerlichen Gesetzbuch, J. Schweitzer, Berlin, 1980 .

COSTA, Ricardo- " Disregarding or not disregarding: that is the question ", BOA N.30 ( 2004), P.10-14

2002. The sole shareholder company in Portuguese law, Almedina, Coimbra,

DOMINGUES, P. de Tarso- Variations on capital stock,

Almedina, Coimbra, 2009 .

DUARTE, Diogo Pereira-Aspects of the survey of the collective personality in the societies in relation of dominion, Almedina, Coimbra, 2007.

DUARTE, R.Pinto - " The under-capitalization of societies in commercial law ", Fisco n. 76/77 ( 1996), p. 55-64;

CUNHA, Paulo Olavo- Business law , 2nd ed., Almedina , Coimbra, 2006, 3rd ed., 2007.

Embid Irujo , José Miguel: El survey del fleece una vez más, la comment for sentences of 20 Junio 1991 La Ley, number del day 11 Febrero 1992.

FURTADO, J. Pinto- Comment on the Commercial Companies Code (Articles 1 to 19 ), Almedina, Coimbra, 2009.

FRANCESCO- Le instituzioni dell economy capitalísticaSocietà per azioni , Stato and classi sociali, 2nd ed., Zanicheli , Bologna, 1980 .

GONÇALVES, OKSANDRO. The Desregard and the principle of morality in the new Civil Code in Journal of Business Law, n.1,2004 .

RIBEIRO, Maria Fátima - The protection of the creditors of the company by quotas and the " disregard of legal personality ", Almedina Coimbra, 2009.

RODA, Bilberry, " levantamiento del velo y legal persona en el derecho Spanish private" , Aranzadi, Pamplona, 1996. 
DISREGARD OF LEGAL ENTITY

E-ISSN 2316-8080

KOURY, Suzy Elizabeth Cavalcante. - The disregard

of

legal personality (disregard doctrine) and groups of companies, $2^{\mathrm{a}}$ ed., Rio de Janeiro: Forense 1998.

Disregard of legal personality(disregarddoctrine) and groups of companies . Rio de Janeiro: Forensic, 2000.

MOTA, A.Mota- Of the supply contract-The financing of the company between capital and foreign capital, Almedina, Coimbra, 2002.

MARTINS, Alexandre Soveral," The personality and ability law of commercial companies" in AAVV (coord. Of Coutinho de Abreu), Law Studies Corporation, 9th ed, Almedina, Coimbra, 2010.; 10th ed., 2010.

MARTINS, JPFazenda - The effects of registration and mandatory publications on the formation of commercial companies, Lex , Lisboa, 1994.

MOREIRA, Guilherme , " Of collective responsibility ", RLJ, 40

OLIVEIRA, José Lamartine Correia The double crisis of legal personality . São Paulo: Saraiva, 1979.

PAZ-AIRES, Candido, these companies Mercantiles, in Lecciones of derecho market, 10th lesson AAVV, ( Director Aurelio Mendez ), 2nd ed., L homson Civitas, Madrid, 2004.

PINTO, Carlos Alberto da Mota, colab. Monteiro António Pinto and Pinto Paulo Mota, General Theory of Civil Law, 4th ed., Reprint, Coimbra Editora, Coimbra.2012.

REQUIÃO, Rubens. Journal of the Courts, n.410 / 15.

REQUIÃO, Rubens Abuse of law and fraud through legal personality. Journal of the Courts, No. 410/17.

SENTO-SÉ-Jairo, Disregard of legal personality in Revista dos Mestrados in Economic Law of the Federal University of Bahia. Salvador: UFBA, vol. 4 ( July 1993 to December 1995)

SERICK, Rolf. Appearance and reality in mercantile societies : the abuse of right by means of the legal person . Barcelona: Ediciones Ariel, 1958. 
SERRANO Gonzalez Murillo, José Luis Merino y Jara, Isac: "Levantiamento del velo "y fiscal offense ( al hilo de la STS, Room 2nd, 20 Mayo 1996), News Juridica Aranzadi , año VI, núm.264, pp.1-6.

TAVARES, José, Societies and commercial companies, 2nd ed., Coimbra Editora, Coimbra, 1924

TRIUMPHANT, Armando Manuel and Triunfante, Luís de Lemos, Disregard of legal personality: doctrinal synopsis and jurisprudence, in Julgar, 2009

Vasconcelos, P. Pais de- The social participation in commercial companies, 2nd ed., Almedina, Coimbra, 2006 .

1 General theory of civil law, 2nd ed., Almedina, Coimbra, 2003.

[1] It is used interchangeably " legal person and legal person" v. COUTINHO DE ABREU, Course on Commercial Law, Vol. II, 4th Ed., Societies, Almedina, Coimbra, 2011, p. 176 et seq .

[2] This thesis is written by MARIA DE FÁTIMA RIBEIRO, The Guardianship of the Creditors of the Societies for Quotas and the "Disregard of Legal Personality ", Almedina, Coimbra, 2009.

[3] This is the commentary to the Commercial Companies Code (CSC), coordinated by Professor COUTINHO DE ABREU, it should be noted in the comments on article 5 on "Personality", a conformation with what was treated by said coordinator of comments to the CSC, in his book Course of Commercial Law, ob., Cit. and the thesis of the same titled Da entrepreneurship. The Companies in the Law, Almedina, Coimbra, 1996, pp. 205-210.

[4] V. JAIRO SENTO-SÉ, Disregard of legal personality, in Journal of Masters in Economic Law of the Federal University of Bahia. Salvador: UFBA. ISSN 1516-6050, Vol. 4, p. 281.

[5] V. JAIRO SENTO-SÉ, Disregard of legal personality ... Ob. Cit. , P. 281; cit., KOURY SUZY ELIZABETH CAVALCANTE, Disregard of legal personality (disregard doctrine ) and Business groups , 1st ed, 1993, Forensic Publishing, p. 67.

[6] V. The arm coordinated by COUTINHO DE ABREU, part of SOVERAL MARTINS, "On the personality and legal capacity of commercial companies " in AAVV, Studies of Company Law, 9th ed., Almedina, Coimbra,

2010; 10th, P. 109, cit. , COUTINHO DE ABREU, Of entrepreneurship ..., p. 210, Course ... vol II, Ob. Cit ., P. 177.

[7] V. COURT OF ABREU, Course on Commercial Law, ob. cit ., p. 176 : "Society does not live for itself and for itself, but rather exists for and for the partner (s); this is the instrument (there is therefore close connection between one and the other). On the other hand, the assets of the company are not in the service of the interests of the legal entity "in itself", but of the partner ( s) ".

[8] When it created the Institute of commercial companies, whose essential elements of his notion contained in 980 Article ${ }^{\circ}$ of the Civil Code, I saw in it a viable tool for separation of those who constitute or that it came to be part of the shed either personal or equity, that undoubtedly encouraged and still encourages economic agents, for safeguarding the personal assets, however, currently, see if this figure (commercial companies that have essentially personalidad and legal and distinguished heritage of (s) partner (s) has been used abusively (right Abuse, Article $334^{\circ}$ C. Civ .), v. ABREU COUTINHO, [et.al .] Comments on article 5 of the Companies Code by Quotas, p. 100-101. For this reason, in order to protect the interests of the creditors of the company that otherwise would be called into question by the "mascara" of the legal personality of the company, the institute of "disregard of legal personality" was created, which means that today day, the legal personality of commercial companies does not 
constitute an argument for the partner (s) to avoid fulfilling their obligations to third parties if it is proved that there has been an abuse of law, ie that the company was used to harm creditors. With this, we think that we create $\mathrm{m}$ conditions for formal disincentive to entrepreneurship and the revitalization $\mathrm{d}$ societies on behalf collective that seemed $\mathrm{m}$ be hibernated .

[9] V. FÁtimA RIBEIRO, A Tutela .... Ob. Cit . pp. 99-132, v. also PEDRO CORDEIRO, The Disregard .... Ob. Cit. pp. 29-35; pp. 53-61. These authors present the different currents that have arisen to discuss the problem, some in favor of disregarding others against, suggesting against them, the idea of normal application of the Right to the concrete case, without the need to resort to disregard, as this according to them would make the institute of collective personality vulnerable, " one of the great inventions of law. The underscore is ours. We will return to this point later.

[10] Throughout this work we will use the term "disregard of legal personality or disregard of the collective personality"

[11] This subject is also treated in addition to the authors of the house (Faculty of Law of the University of Coimbra) that we will follow to a great extent, among others, by MIGUEL JAPUPO COR REIA, with the collaboration of ANTÓNIO JOSÉ TOMÁS AND OCTÁVIO CASTELO PAULO , Commercial Law. Company Law, 12th ed., Revised and enlarged, EDIFORUM, Edições jurídica, Lda., Lisbon, pp. 195-198, under the heading, Personality of Commercial Companies .

[12] The expression person legal was introduced in Portugal by GU I LHERME Alves Moreira, with his work. Institutions of Portuguese Civil Law. Volume first. Part General Press of the University of Coimbra, 1907, pp. 135 et seq .

[13] V.OKSANDRO Gönc ALVES, The Disregard doctrine and principle of ethics in the new Civil Code, in Journal of Business Law ISSN 1806-910X.NI (2004), p. 147, cit., MOTA PINTO, General theory of civil law, Coimbra, 1996, p. 126. Among the various theories, the predominant one is that proposed by Savigny: "For some authors, like SAVIGNY and WINDSCHEID, legal persons would be a fiction. The collective personality would be a fictio iuris (theory of fiction). The law, establishing the legal status of those legal, would be proceeding as if legal persons were natural persons, since only natural persons can be subjects of rights and duties. "

[14] V.OKSANDRO GONCALVES, A Disregard doctrine ... .Ob. cit. , P. 148, cit., MENEZES CORDEIRO, The survey of collective personality in civil and commercial law, Coimbra: Almedina, 2000, p. 39.

[15] V. JAIRO SENTO-SÉ, Des consideration of the personality ... Ob. Cit ., P. 281.

[16] V. JAIRO SENTO-SÉ, Disrespection of the personality ... Ob. Cit. , P. 282.

[17] JAIRO SENTO-SÉ, Des consideration of the personality ... Ob. Cit. , P. 282.

[18] It is thus perceived that the legal personality is not natural of legal persons but is conferred by the legal order complied with that are the legal requirements established for this purpose.

[19] CARLOS ALBERTO DA MOTA PINTO, ANTÓNIO PINTO MONTEIRO and PAULO MOTA PINTO, General Theory of Civil Law, 4th edition, reprint, Coimbra Editora, Coimbra, 2012, p. 269. About personality c olectiva will use this work despite although not the only one on the subject as before I'll see s. T has been referenced by the authors hitherto indicated, MANUEL DE ANDRADE, in his Theory of Legal Relationship, which is considered the greatest treatise on the General Theory of Civil Law of the 20th Century in Portugal. In the next references to the work of the first authors presented in this note, we will only use the most outstanding name with which the work is identified, even in Mozambique, our homeland, (MOTA PINTO)

[20] MOTA PINTO, General Theory ... Ob. Cit . , P. 269.

[21] COUTINHO DE ABREU, Course on Commercial Law, 4th ed., Vol. II, Almedina, Coimbra, 2011 , p. 163 Note 5 , cit., SAVIGNY with the " theory of fic tion" as one of the pioneers in the discussion of the legal nature of the legal personality in his work Traité de droit romain, trad., T.II, F. Didot, Paris, 1841, pp. 234,237-239) and the theory of the " real legal person " in which O. GIERKE is the greatest representative.

[22] ABREU COUTINHO, Course ... Ob. cit. , P. 164.

[23] V.COUTINHO DE ABREU, Course ... Ob. Cit. , P. 164.

PIDCC, Aracaju/Se, Ano VIII, Volume 13 no 02, p.222 a 251 Jul/2019 | www.pidcc.com.br 
[24]V. COURSE OF ABREU, Course ... Ob. cit. , Pp. 164-170. Argues in these pages that should not absolutize the institute of legal personality of the people collective as an indispensable condition for its operation, assuming that there are entities that although stripped of the garment of legal personality, normally carry out their activities .

[25] We refer to the development of this theme in light of MOTA PINTO, General Theory of Civil Law, Ob. Cit. , Pp. 269 et seq.

[26] Idem., Ob. Cit. , P. 269.

[27] Idem ., Ob. Cit. , P. 269.

[28] Id., Ob. Cit. , p. 669.

[29] Ibid., P . 270. The idea of common interests is also enshrined in Article 980 of the Civil Code, on "essential elements or notes of the general concept of society", COURT OF ABREU, Course .... Ob . Cit ., Pp. 5-23.

[30] MOTA PINTO, General Theory ... Ob. Cit. , P. 270.

[31] MOTA PINTO, General Theory ... Ob. Cit. , P p. 270-271.

[32] MOTA PINTO, General Theory ... Ob. Cit. , P. 271, cit ., MANUEL DE ANDRADE, General theory of legal relationship, cit ., I, pp. 47-49. In fact the personality collective (legal) is a mechanism that allows enduring pursuit of common interests as they say the authors just quoted, but is not essential as there are people legal fact that can endure and continued $r$ smoothly their various purposes. The case of unrecognized associations and the societies themselves before their definitive recognition, practice through the legal personality of their partners or associates, legal acts whose effects are reflected in the sphere of third parties and of the de facto person himself. In fact, this has already been duly refuted by COUTINHO DE ABREU, v. cit ., 13 supra.

[33] MOTA PINTO, General Theory ... Ob. Cit. , P. 280.

[34] Idem ., Pp. 280-281 " Various modes of recognition are possible. Normative recognition can take place, this is automatically derived from the law and an individual recognition or by concession, this is translated into an individual and discretionary act of a public authority that, in each case, personify or not the substrate. Normative recognition can take two forms. It may be an unconditional recognition if the legal order gives legal personality de ple, without further requirements, to the whole substrate of the legal person (system of free constitution of legal persons $\quad$ ). Such a system will hardly exist in any positive law, and it does not exist among us. It may be a conditional normative recognition. This type of recognition is also of a global nature, that is to say, derived from a legal norm directed to a generality of cases and not from an individual assessment, on a case-by-case basis. This type of recognition also translates into a degree of freedom and ease in the constitution of legal persons that is superior to recognition by concession. The law generally formulates the requirement of certain assumptions or requirements, which must be added to the characterizing elements of a substrate and, verified these requirements,

the legal person is automatically constituted, without the need for an appreciation of opportunity and convenience on the part of the State ", MOTA PINTO, General Theory ... Ob . 280

[35] V. The arm coordinated by COUTINHO DE ABREU, on the part of SOVERAL MARTINS, "On the personality and legal capacity of commercial companies" in AAVV (Coutinho de Abreu coord.), Studies on Company Law, 9 th and d. , Almedina, Coimbra, 2010; 10a , p. 94, cit., JOSÉ TAVARES, Societies and commercial enterprises, 2nd ed., Coimbra Editora, Coimbra, 1924, pp. 147 et seq ., Pinto Coelho, Lessons in Commercial Law. Mercantile obligations in general. Market obligations in particular ( commercial companies), author's edition, Lisbon, 1996, p. 217 et seq .; MANUEL DE ANDRADE, General theory of legal relationship, I, Almedina, Coimbra, 1983, reimp ., p . 83, Ferrer Correia, Lessons ..., II, cit ., Pp. $85 \mathrm{sec}$

[36] V. The arm coordinated by COUTINHO DE ABREU, in the part of SOVERAL MARTINS, "On the personality and legal capacity of commercial companies" in AAVV, Studies of Company Law, 9th ed., Almedina, Coimbra, 2010; $10^{\text {a }}$, pp. 95-96.

[37] Idem, p. 97.

[38] 28. V. The arm coordinated by COUTINHO DE ABREU, in the part of SOVERAL MARTINS, "On the personality and legal capacity of commercial companies" in AAVV, Studies of Company Law, 9th ed., Almedina, Coimbra, 2010; $10^{\text {a }}$ ed., 2010 , p. 97. 
[39] V. The arm coordinated by COUTINHO DE ABREU, on the part of SOVERAL MARTINS, "On the personality and legal capacity of commercial companies " in AAVV (Coutinho de Abreu coord.), Studies on Company Law, 9th ed. Almedina, Coimbra, 2010; 10a ed., 2010, p. 97. This aspect of the separation of legal personality of the company and its partners, once distinct, must be strictly respected by partners and society, failing to raise the problem object of the present work "Disregard of legal personality", when the rights of creditors will be called into question for non-compliance with the principle of separation of legal personality and consequently of assets.

[40] V.PUPO CORREIA, Commercial Law ... Ob. Cit. , P. 202, annotation 308, points out a series of authors who study this matter.

[41] V.COUTINHO DE ABREU, From Entrepreneurship ... Ob. Cit. , Pp. 205-210.

[42]V. PEDRO CORDEIRO, The disregard of the legal personality of commercial companies, 2nd ed, Colecção Teses, Universidade Lusíada Editora, Lisboa, 2005, p. 27, for further developments cit ., J.LAMARTINE CORREAA DE OLIVEIRA, "The Double Crisis of the Legal Person," cit ., P. 264 ff., PIERO VERRUCOLI,

"II overrun of the personalità giuridica delle societádi capitali nella common Law and nella civil Law, "Milan, 1964, with special reference to German, Swiss and Austrian law and German authors.

[43] V. FÁTIMA RIBEIRO, A Tutela ... Ob. Cit. , P. 95, annotation 29.

[44] V.PEDRO CORDEIRO, The Disregard ... .Ob. cit. , Pp. 27-29.

[45] Other denominations of the theory of disregard of legal personality, according to JAIRO SENTOSÉ, Desconsider action of legal personality ... Ob. Cit., p.282. "The theory that we will be studying has been consecrated in several countries of the world, where it has received the most diverse labeling. In the Saxon-Saxon countries, it is known as disregard of legal entity, lifting the corporate veil, piercing the corporate veil -correlation of the corporate veil-and craking open the corporate Shell. In countries Roman-Germani cos, has other denominations . In italy it was labeled as superego della personalittà giurídica . In Germany, for its part, it is called durchscriff der juristichen person-penetration of the legal person. Argentine law usually conceives it as a theory of penetration or rejection of personality. "

[46] V. FÁTIMA RIBEIRO, A Tutela ... Ob. Cit. , p. 99 and ff

[47] V. OKSANDRO GONCALVES, A Disregard doctrine ... Ob. Cit. , p. 151.

[48] V. OKSANDRO GONÇALVES, A Disregard doctrine ... Ob. Cit. , p. 151.

[49] V. OKSANDRO GONÇALVES, A D isregard doctrine ... Ob. Cit. , p. 151.

[50] Therefore, the partner or partners hide behind society to achieve their evil attempts against creditors.

[51] V. FÁtimA RIBEIRO, A Tutela ... Ob. Cit., Pp. 104-105.

[52] V. OKSANDRO GONCALVES, A Disregard doctrine ... Ob. 151-152; cit ., ROLF SERICK, Appearance and in mercantile societies-abuse of law for fear of the legal person. Barcelona: Ediciones Arial , 1958, p. 242-258.

[53] V. FÁTIMA RIBEIRO, A Tutela ... Ob. Cit., p. 107. gra $\mathrm{n}$ of criticism which makes the formulation of SERICK, has to do with the fact that you understand that abuse of rights is knowable objectively, otherwise would prevent the unenlightened that they could rely on that figure, the path of subjectivity of abuse of rights would raise many difficulties on the question of proof.

[54] V. FÁTIMA RIBEIRO, A Tutela ... Ob. Cit. , Pp. 107-108. The theory defended by the institutionalists points to the problem of "disregarding the legal personality" when using society as such (institution), in violation of the established legal-economic order.

[55] V. FÁTIMA RIBEIRO, A Tutela ... Ob. Cit. , Pp. 107-108. The theory of the application of the norm says that the legal person is an image, what matters is the set of legal rules to be applied when raising a question regarding liability of the partner or society before third parties. It is clear that these norms that MULLER's theory defends have as one of the purposes the separation of the legal personality of the society from the legal personality of the partners as biologically formed persons. 
[56] V. FÁTIMA RIBEIRO, A Tutela ... Ob. Cit .., pp. 110-111. This theory, as we see in the explanation of the last part of the text, defends the strict respect of the collective personality in the following saying: "the solution can not consist in the disregard of the legal personality of this association, nor in its relativization". This (respect the legal status of those legal ), seems to be the position taken by the author that we have been following in this part of this work, as can be seen on pages 125 to 132 of the cited work.

[57] V. FÁTIMA RIBEIRO, A Tutela ... Ob. Cit. pp. 111-112.

[58] According to FÁTIMA RIBEIRO, A Tutela ... Ob. Cit. , pp-125-132.

[59] V. FÁTIMA RIBEIRO, A Tutela ... Ob. Cit. , p . 125. This paragraph makes clear the position of the author with regard to the dogmatic construction of the institute of "disregard of legal personality", which is aimed at removing it, as it is a threat to the theoretical and practical rigor of the figure personality collective, position with which we agree, without taking the permanent merit concern of doctrine and jurisprudence in finding mechanisms weakening scams that use the masks of the legal personality of the people collective to damage to third parties (social creditors) .

[60] V. FÁTIMA RIBEIRO, A Tutela ... Ob. Cit. , Pp. 125-131.

[61] V. FÁTIMA RIBEIRO, A Tutela ... Ob. Cit. , p . 131.

[62] Idem FÁTIMA CORDEIRO, The Guardianship ... Ob. Cit. , p. 131-132.

[63] V. In this sense, COUTINHO DE ABREU, Course ... Ob. Cit. , p. 176.

[64] V. ABREU COUTINHO, Course ... Ob. Cit., P. 176, in the same direction the Code of Commercial Companies commented on, AAVV, coordinated by COUTINHO DE ABREU, article 5, pp. 100-101; v. also, COUTINHO DE ABREU, of Entrepreneurship ... Ob. cit., p. 197 et seq.also., SOVERAL MARTINS, "The personality and legal capacity of commercial companies " in AAVV ( Coutinho de Abreu coord.), Corporate Law Studies , 9th ed., Almedina, Coimbra, 2010; 10ª ed., 2010, p.105-110.

[65] ABREU COUTINHO, Course ... Ob.

[66]V. PEDRO CORDEIRO, The Disregard ..... Ob. Cit., P. 19. The two definitions given are not irreconcilable.

[67] V. ABREU COUTINHO, Course ... Ob. cit. , p. 178, in an opposite sense MEZEZES CORDEIRO, From the survey of the Collective Personality. Law and Justice. 0671-0376-vol. 4, 1989/90, p. 147-161, specifically on p. 159, understands that the implementation of the figure of the "survey", as far as we disregard of runs two factors namely:

- the scope of the principle of good faith;

- the legal regime in force as sole proprietorships.

[68] V. ABREU COUTINHO, Course ... Ob. cit. , p . 178.

[69] V. COURT OF ABREU, Course ... Ob. Cit. , P. 178.

[70] V. ANGEL RICARDO Yaguez, La doctrine of "levantamiento del velo" de la legal persona en la jurisprudence, 4th ed., Publisher Civitas, Madrid, 1997, p. 55. It is not easy to perceive a priori (at the time of the incorporation or soon after) that y was constituted with "fraudulent" interests, this perception arises from interpretations submitted to the behavior of the partner (s) when they are rights of third parties. The cases that lead to disregard have been pointed out, are the development of the study made by ROLF SERICK, precursor of the doctrine of disregard.

[71] V. RICARDO DE ANGEL YAGUEZ, The doctrine ... Ob. Cit. , p . 55; v. considerations made in the previous note on the list of relevant cases leading to disregard.

[72] Ibid., V . RICARDO DE ANGEL YAGUEZ, The doctrine ... Ob. Cit. , P. 55; this construction does not escape the one presented by COUTINHO DE ABREU, (cases of imputation and cases of responsibility).

[73] Imputation cases for the purposes of this study occur when certain knowledge, qualities or behavior of members are referred to or imputed to society and vice versa, according to COUTINHO DE ABREU, Course ... Ob. Cit ., P. 179, presents in detail these cases with quite elucidative examples.

[74] V. ABREU COUTINHO, Course ... Ob. Cit. , Pp. 179-180, v. Art. 5 of the CSC in comment, Ob.cit., AAVV, coordinated by COUTINHO DE ABREU, pp. 101-102, cit ., ABREU 
COUTINHO, From Entrepreneurship ... pp. 342, ss, cit ., Judgment of the RP of 17/2/2000, CJ, 2000 ,, I, cit ., Judgment of the RP of 13/5/93, CJ, 1993, III, p. 199.

[75] V. PEDRO CORDEIRO, The Disregard ... Ob. Cit. , Pp. 23-24; Under the heading PROBLEM PUTTING presents in points a) to $\mathrm{u}$ ) a diverse set of imputation situations some cases coincide with the allocation made by COUTINHO DE ABREU, in its course ... ..ob . cit ., pp. 179 et seq .

[76] Liability cases occur when the limited liability or non-liability rule is broken to be called the members of a limited liability company or an anonymous company ( partnership-based, mixed assets, undisclosed material capitalization). COUTINHO DE ABREU, Cur so ... Ob. Cit ., P. 178, well developed.

[77] MENEZES LAMB. From the survey of the Collective Personality. Law and Justice. 0671-0376, vol. 4, 1989/90, p . 147-161.

[78] MENEZES LAMB. From the survey ... ob. cit ., p. 155.

[79] V.COUTINHO DE ABREU, Course ... Ob. cit. , Pp. 176-187; The position of this Prof, which is favorable to disregard, is very clear, we opted to a great extent for its approach as the most followed in the University of Coimbra and much referenced in the Portuguese doctrine, being attributed to it the reactivation of the study of the disregard of the collective personality, v. to this end, the following note, also other positions in OKSANDRO Gonçalves ... The Disregard docrtine ... Ob. Cit. , p . 164; JAIRO SENTO-SÉ, Disregard of personality ... Ob. Cit. , p. 293294

[80] This title we extract from the work considered first to give treatment this matter in Portugal, PEDRO CORDEIRO, The Disregard ... Ob. Cit., Pp. 37-52, according to FÁTIMA RIBEIRO, The Guardianship ... .Ob. cit. , p. 306 "[....] In the meantime, PEDRO CORDEIRO published, in 1989, the first national monograph on the subject, the study The Disregard of the Legal Personality of Commercial Companies; the same author in his thesis highlights the role of Professor COUTINHO DE ABREU in the doctrinal approach of this "institute" when saying that: It is due to COUTINHO DE ABREU, in work of 1983, the return to the question of "disregarding the collective personality "Which the author presents as a consequence of a" substantialist "idea, not absolutizing " the legal personality - only then will the possibility of "taking into account the personal and / or patrimonial substratum" of society, which will the veil "of personality (" treating as transparent "this legal personality of the person collective) to derogate from the" principle of separation v. FÁTIMA RIBEIRO, A Guardian .... . Ob. Cit. , p. 305, cit., COUTINHO DE ABREU, From Abuse of Law ... cit., Pp. 105 et seq. In the thesis of FÁTIMA RIBEIRO, A Tutela ... Ob.cit ., the matter of disregard in Portuguese Law is developed on pages 299-347. [81] Curiously, MENEZES LAMB, Of lifting ... ob. cit., p. 151, note 21, attributes the pioneer position in the use of the term "disregard" in Portuguese doctrine Professor OLIVEIRA RISE WILL, in the following words: "... the Portuguese doctrine pioneer-so OLIVEIRA RISE, Right Lessons Commercial - Vol.I -Part General ( 1986/87), uses the term "Disregard" of personality; ... ", which contrasts with the idea of the doctrinal approach of disrespect to have been taken up by Professor COUTINHO DE ABREU in 1983, v. previous annotation, 80, supra .

[82] V.PEDRO CORDEIRO, The Disregard ... Ob. Cit. , Pp. 37-39.

[83] V.PEDRO CORDEIRO, The Disregard ... Ob. Cit. , Pp. 37-39.

[84] Ibid ., P . 39 , note 34, "The dispute giving rise to the opinions of Profs. ANTUNES VARELA AND

FERRER CORREIA, was finally resolved by agreement of the parties, thus not giving rise to any judicial decision."

[85] For details of the facts relating to this case, see PEDRO CORDEIRO, The Disregard ... Ob. Cit. , p. 41.

[86] V. FÁTIMA RIBEIRO, A Tutela ... Ob. Cit. , Pp. 300-301, in the same sense PEDRO CORDEIRO, The Disregard ... Ob. Cit. , p . 44.

[87] ARMANDO MANUEL TRUNFANTE and LUÍS DE LEMOS TRUNFANTE, " The Disregard of the legal personality - Synopsis of doctrine and jurisprudence " in Julgar, 2009, p. 131.

[88] V.PEDRO CORDEIRO, The Disregard ... Ob. Cit. , p. 51.

[89] V.COUTINHO DE ABREU, Course ... Ob. Cit. , p. 177.

[90] V. COUTINHO DE ABREU, Dialogues with jurisprudence, II-Responsibility of the Directors to the social creditors and disregard of legal personality, Company Law in Review (DSR), Alm edina, Coimbra, 2010, pp. 
52e53. " In order to be reimbursed, social creditors often resort indiscriminately to the responsibility of the managing partners through art . 78, 1, of the CSC and by disregarding the legal personality of companies. They are different and alternative paths. Responsible persons, according to art. 78, 1, are the managers (de jure or de facto), whether they are members or non-members; the managing partners respond to the social-verified creditors the presuppositions of that precept-as managers (in the exercise of management and / or representation), not as partners. By disregarding the legal personality, only partners (as such) are affected, not managers; the managing partner is held accountable for being a partner, not for being a manager. Being the behaviors of the managers (partners) that come within the scope of application of article 78, 1, it is necessary to go here, not by the disregard of the legal personality. In the case of certain behaviors of the partners ( managers) as partners, it may be due to the disregard of the collective personality . " Thus, according to COUTINHO DE ABREU, O n. 1 of Article 78 of the CCC does not apply to piercing the corporate veil.

[91] MENEZES LAMB, Of lifting ....... ob . cit ., p. 159, states that: " The application of the figure of the survey of collective personality in Portugal presents no difficulties." This position is completely contrary to the various judgments in Portugal on this matter.

[92] The formulation of 87 Article No. of Mozambique Commercial Code that first introduces the figure disregard of legal entity, is shown apart from doctrine theoretical assumptions concerning this figure, at least the aspects that have been generally studied on school subjects. Eg to. Mention - is the abuse of economic power, it is not sufficiently clear what constitutes this abuse, the reference to environmental rights, are among others, aspects Quality and raise serious questions. On the other hand, Mozambique does not yet have special legislation on groups of companies. Revisions of different legislation in our legal system, shall also comply with strict scientific criteria.

[93] V. FÁTIMA RIBEIRO, A Tutela ... Ob. Cit. , Pp. 311-326, tb ., COUTINHO DE ABREU, Dialogue with jurisprudence ... Ob. Cit. , Pp. 49-52.

[94] ABREU COUTINHO, Course ... .. Ob. Cit. , p . 187, defends a contrary position when he says: "Despite the criticisms that have been addressed (" dogmatic "deficits, sharpness, certainty and security, etc.), the figure of the disregard of collective personality (and legal subjectivity) reveals itself capable of counteracting some dysfunctions of societies perpetrated by partners. "

[95] Preferred terminology for ABREU COUTINHO, Course ... Ob. Cit. , p. 183.

[96] Author cited by ARMANDO MANUEL TRUNFANTE and LUÍS DE LEMOS TRUNFANTE, " The Disregard of Legal Personality - Synopsis of Doctrine and Jurisprudence " in Julgar, 2009, p. 137.

[97] When referring to traditional societies, we have in mind the initial conception, simple societies, constituted only by natural persons, as opposed to the present-day scenario, in which we have affiliated societies (in a complex of juridical relations) according to Art. $481^{\circ}$ and ss of the CSC. The problem of disregard is not raised in relation to companies in a collective name by their natural legal regime, art. $175^{\circ} / 1$ of the CSC.

[98] Derogation not the principle of separation of the legal status of the members face society, but of the assets, where does " separation between the corporate entity ", would be " separation between corporate assets." The solution would be for raising the separation of the veil heritage and not the legal status as such. the corporate legal entity is not necessarily linked to its assets in general, but their capital, v. als.f, $g$ and $h$ ) Art.9 thereof in conjunction with Art. $5^{\circ}$, all of CSC. so it makes perfect sense derogate the principle of separation of the assets of shareholders and of society without calling into question its personality, unless the share capital is affected. In fact this seems to be the position of Prof. COUTINHO DE ABREU, Course ... Ob. Cit. , p . 176, by defining the disregard of the corporate legal personality of companies as the "derogation or non-observance of the legal-subjective and / or patrimonial autonomy of companies vis-à-vis their respective partners".

[99] V. COURT OF ABREU, Dialogues with jurisprudence ... .. Ob. Cit. , P. 51, cit . Ac . of the RP of 10/15/01. 